\title{
Factor Affecting Consumer Satisfaction in Cashless Payment Systems in India with Respect to Paytm and BHIM
}

\author{
Neelu Tiwari, Naveen Kumar Singh
}

\begin{abstract}
Despite the massive adoption of Information and Communication Technology, in the field of digital payment systems, there are very few researches on consumer satisfaction with cashless payment systems. This exploratory research is the first to test consumer satisfaction level towards cashless payment systems through two leading companies (Paytm and BHIM), providing digital payment platform. The primary objective of the current research study is to identify the factors affecting adoption of cashless payment services and consumer satisfaction in India through survey method. Adoption of cashless payment systems can help society in the development of the economy. Study recommends that companies like Paytm and BHIM need to know the factors affecting 'consumer satisfaction' with cashless payment systems in India. Cashless payment system providers focus not only on the adoption of cashless payment systems but also the satisfaction of the consumers in India. The study also presents a model for enhancing the rate of customer satisfaction with respect to e-wallets in India. With the help of close-ended questionnaire, total 200 respondents have been participated in the survey. Through comparative analysis it is found that BHIM to be a much more secure platform as compared to Paytm since it is a government-owned platform. However, Paytm aids in providing an instant solution to problems but has a few disadvantages.
\end{abstract}

Index Terms: Cashless transactions, Consumer Satisfaction, Digitalization, Interface, e-Wallets, BHIM, Paytm

\section{INTRODUCTION}

A. An introduction to the advent of the cashless payment system in India

The increasing usage of the internet, smart phones and excessive initiatives taken by government bodies towards digital payment have led to the exponential growth of cashless payment companies in India. The cashless payment system in India was introduced under the flagship program of Digital India Initiative by the Government of India [1]. The government intended to combat black money, corruption, counterfeit currency and terror financing [2, 3, 4]. The initiative aided in developing a cashless mode of transactions via the use of credit cards, debit cards or digital devices like point-of-sales machines, and digital wallets [5]. Further, the enactment of demonetization by the government in 2016 led companies like Paytm to aggressively expand such cashless mode of transactions into the Indian market. This initiative enforced retailers as well as wholesalers to carry out cashless transactions. Small vendors, who had traditionally been

Revised Manuscript Received on October 25, 2019.

Neelu Tiwari, Jaipuria Institute of Management, Ghaziabad, India, neelutiwari82@gmail.com

Naveen Kumar Singh, School of Management Studies, Motilal Nehru National Institute of Technology Allahabad, Prayagraj, India, rajput.naveen07@gmail.com limited to cash as a mode of the transaction were made to integrate Paytm and similar services to carry out their small cashless transactions $[6,7,3]$. This also limited the circulation of liquid money to a minimum. Hence, with the advent of advanced technology in addition to government initiatives, the cashless payment system started to take more grip in India.

\section{B. Introduction to Paytm and BHIM}

Paytm is an e-commerce site which was initiated by Vijay Shekhar Sharma in August 2010 by making a preliminary investment of $\$ 2$ million in Noida [7, 8, 9, 10]. Paytm is currently accessible in 10 different Indian languages offering a number of services. It facilitates to make online payments to mobile recharges, utility bill, grocery stores, fruits and vegetable shops, restaurants, parking, tolls, pharmacies, and educational institutions etc. by using Paytm QR code [11, 12]. Many travel, movies, and events ticket bookings, etc. could be done through it. Paytm since its inception has shown immense growth in the registered Paytm Users. The user strength has increased to 104 million in August 2015 from 11.8 million in August 2014 [13]. It has also become India's first payment app which has crossed 100 million app downloads in the year 2017.

Bharat Interface for Money (BHIM) is a mobile application which was build up by National Payments Corporation of India (NPCI) under the leadership of Prime Minister Mr. Narendra Modi on December 30, 2016 [14]. It provides its users to make fast and fitting cashless digital payments with the use of Unified Payment Interface (UPI) which makes the payment safe and secure. Data reveals that the app has been downloaded more than 3 million times with the use of Google Play and about more than 500,000 transactions have been made using it $[15,16]$. BHIM has linked about 100 million Indians to the cashless digital payment ecosystem. The aim of our study is to analyze and compare the factors that affect consumer satisfaction with cashless payment systems in India with reference to Paytm and BHIM.

\section{LITERATURE REVIEW}

A. Factors affecting the adoption of cashless payment services in India

According to the previous studies $[16,17,18,19]$ consumers in India are highly attracted by the money transfer feature provided by the cashless payment services in India.

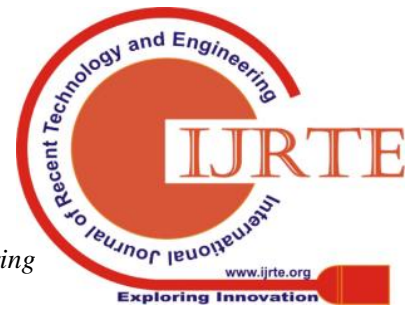




\section{Factor Affecting Consumer Satisfaction in Cashless Payment Systems in India with Respect to Paytm and BHIM}

The individuals can receive and send money to near and dear ones in a quick and easy manner anytime and anywhere by using e-wallets. These e-wallets also allow transfer of money instantly by using Immediate Payment Service (IMPS) platform which works $24 \times 7$ with no limitation to holidays or odd hours. These e-wallets as an application in mobile add to the feature to transfer money even when the bank is on strike or closed [20]. The cashless payment services in India can be used for a variety of purposes, like bill payment, ticket booking for bus, flights, recharge, shopping could be done easily in the comfort zone of home and at own convenient time without the need to go to the particular store or place to make the payment [21]. As per the study of Rajanna [4], various cashless payment systems available in India provide guaranteed return facilities. For instance, while making payment if any consumer is not satisfied can rise a concern and can avail the money back within a few hours. Additionally, it is also not required necessarily to mention the cause of concern for return hence, providing full control over the money [22]. The usage of cashless payment services for transfer money or making payment provides benefits of cash back offers and other related offers increasing the value of consumer money.

\section{B. Factors affecting consumer satisfaction}

Oliver [23] defines customer satisfaction as the emotional response and pleasure generated when a customer's needs or goals are fulfilled by a product or service. Consumer satisfaction is a dynamic phenomenon which is affected by a number of factors. Over the decades, a number of studies have been undertaken by various researchers to study the factors which affect consumer satisfaction with respect to various products and services. Understanding customer satisfaction is extremely important in today's business scenario as it helps devise strategies and methods to increase market share through repeat purchases and referrals [24]. Some of the common factors affecting customer satisfaction have been identified as perceived value, image, price, quality, reliability and comfort [25]. A deeper understanding of the phenomenon of customer satisfaction can be gained through a review of popular models devised over the years. Some of them are shown in figure 1 below.

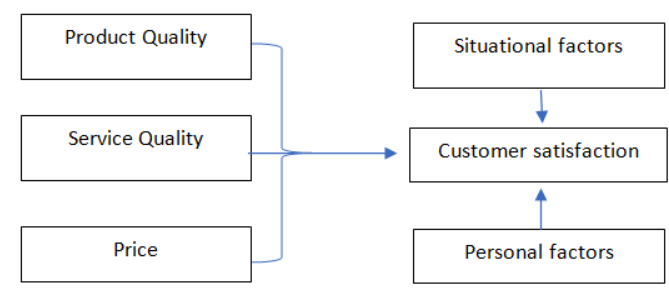

Fig. 1. Customer Satisfaction Model (Source: Duy and Hoang, 2017)

The model (figure 1) depicts that the satisfaction of a customer induces repurchase intentions whole the dissatisfaction results in discontinuation of the same. This model represents different measures in relation to customer satisfaction that acts as a fatal factor in any source of business and its performance [26] and the product quality and its service at a given price essentially vital in satisfaction of the customer [27]. In addition, this model included situational factors in terms of communication between the retailers and customers as the reason to induce the purchase of the product.
Other personal factors included the preferences for certain brands and their services [28].

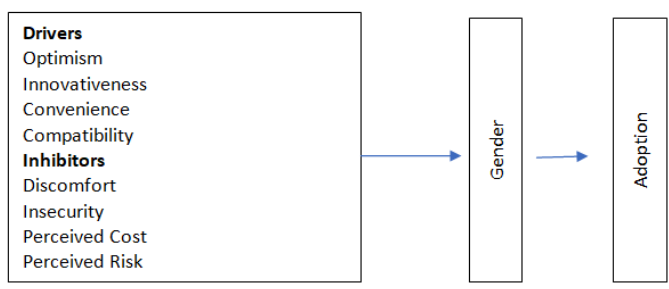

Fig. 2. Technology-Readiness Framework (Source: Olson and Kesharwani, 2010)

As per the figure 2, the researcher included gender in order to determine the factors responsible for the adoption of cashless payment services in India. The adoption of cashless payment services is highly impacted by four drivers which are optimism, innovativeness, convenience, and compatibility [29]. The first driver refers to the willingness of the consumer to adopt and take a decision regarding the adoption of cashless payment services. The optimist behavior of the consumer motivates him/her to integrate innovation into his or her life regarding the adoption or use of technology for the first time.

The study reflects the construct of cashless payment system and satisfaction level of the customer. The following hypothesis need to be check through analysis:

HA: There is no impact of cashless payment services on the satisfaction level of the customers.

\section{Technology Acceptance Model (TAM)}

In 1980, Fishbein \& Ajzen introduced TAM or technology acceptance model as an outcome of the Theory of Reasoned Action (TRA). The model aided in resolving key challenges in relation to the field of information technology [30,31]. To make a decision in the adoption of any new technology by an individual or group is complicated and end results are the adoption or rejection of the technology $[31,32,33]$.

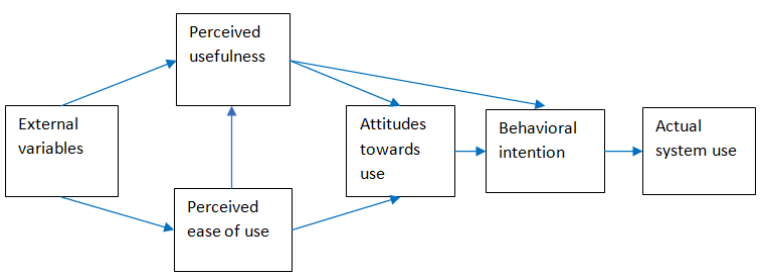

Fig. 3. Technology Acceptance Model (Source: Islam and Gronlud, 2011)

The important factors underlying the acceptance of technology are determined by the attitude and intention of using the product. This, in turn, depends on the use as well as the ease to use the product and thus the satisfaction of customers. All the crucial parameters, which are self-explanatory, of TAM model, are presented in figure 3. 
D. Challenges in consumer adoption of cashless payment services

The usage of cashless payment services is still a challenge for most of the consumers in India due to lack of knowledge and learning about the usage or application of such services. As per the survey conducted by Kalpesh [34], about $44 \%$ of the urban population is using cashless payment services while only about $16 \%$ of the rural population is using cashless services in India. Hence, it could be cited that lack of understanding about the applicability of the cashless services many individuals especially in rural areas is not able to adopt cashless services. Another major challenge is the development of trust. Many people do have faith and trust that the payments done by using cashless services $[35,36]$. The consumers still feel that they might get cheated, experience theft or lose their money to hackers or other security threats while using cashless payment services [37, 38]. While making cashless payment cost of making transaction is imposed on consumers which are not readily accepted by the consumers. According to Maken and Shekhar [39] and Rajanna [4], the mobile wallet companies are found to be imposing about $1 \%$ to $4 \%$ charges for making transactions to bank accounts which lay hindrances in readily accepting the cashless payment services. Moreover, the cashless payment services also impose a limit for the transfer of money. Hence, it could be cited that the restrictions laid down by the cashless payment services impose challenges for the consumers to use it wisely.

\section{RESEARCH METHODS}

\section{A. Sampling and Data Collection}

The research aims to understand the factors affecting the customer satisfaction level with respect to different cashless payment service providers. In the current study, researcher used exploratory research to understand the customer satisfaction level. To this end, we conducted quantitative research approach to record the response from customers of two service providers in India. The purposefully selected two service providers by considering the number of installation of the application in the last few years and they are Paytm and BHIM. A purposive sampling technique has been used to collect data for the quantitative analysis. Using random sampling technique, a total sample size of 200 customers from two service providers were considered for the quantitative survey. A highly structured and close-ended questionnaire was developed. The questionnaire was built using widely recognized models of customer satisfaction, i.e. customer satisfaction model, the technology acceptance model, and technology readiness model. A total of Fifteen days was spent in collecting the data.

\section{B. Measuring Instruments}

For the quantitative analysis of the research study, primary sources were used to collect the required data. Descriptive statistics method is used to understand the demographic and professional profile of the respondents. Inferential statistics were performed on different factors related to customer satisfaction level. Inferential analysis tools used in the present research study are correlation test, ANOVA test, and regression analysis.MS Excel and R software were used for deriving the results with respect to the data gathered from respondents. In addition, all the participants involved in the survey were known about the objective and purpose of this research.

\section{CONCEPTUAL FRAMEWORK}

Following factors were undertaken in existing models of customer satisfaction in relation to the adoption of technology, the present study has been devised on the model depicted below in figure 4 .

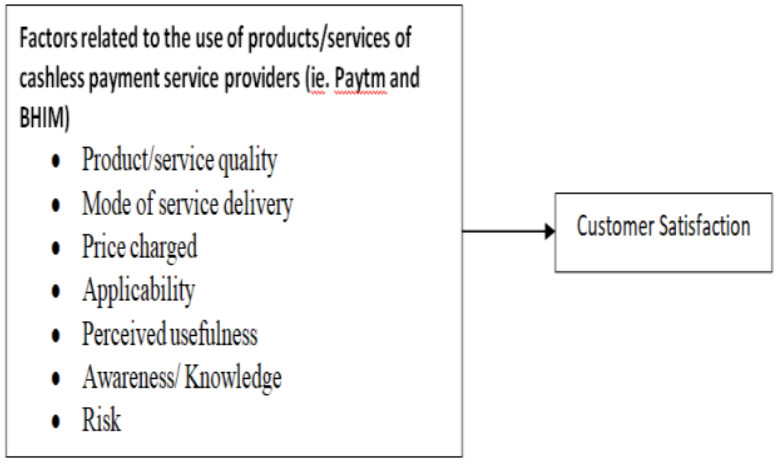

Fig. 4. Proposed Research Model

\section{DATA ANALYSIS AND INTERPRETATIONS}

In this section, to determine factors affecting the customer satisfaction level of the cashless payment service providers, data analysis of the primary data collected from 200 customers of two service providers in India i.e. Paytm and BHIM is represented.

\section{A.Analysis of Demographic Profile}

Figure 5 shows the descriptive analysis of the demographic profile of the customers. Majority of the respondents were males i.e. exactly $57 \%$ for Paytm and $62 \%$ for BHIM. $79 \%$ \& $82 \%$ of the customers were belonging to less than 30years age category for Paytm \& BHIM respectively. Exactly $88 \%$ (for Paytm) \& 86\% (for BHIM) of the respondents had at least under graduation degree as their educational qualification. With respect to the profession, 28\% (for both Paytm \& BHIM) of them were self-employed, 27\% (for Paytm) \& 28\% (for BHIM) were private employees and 22\% (for Paytm) \& $21 \%$ (for BHIM) were students. Over $60 \%$ (for Paytm) \& $71 \%$ (for BHIM) of the respondents were earning above Rs. 20,000 per month. These statistics reflect that these respondents are much educated and suitable for conducting the study. 

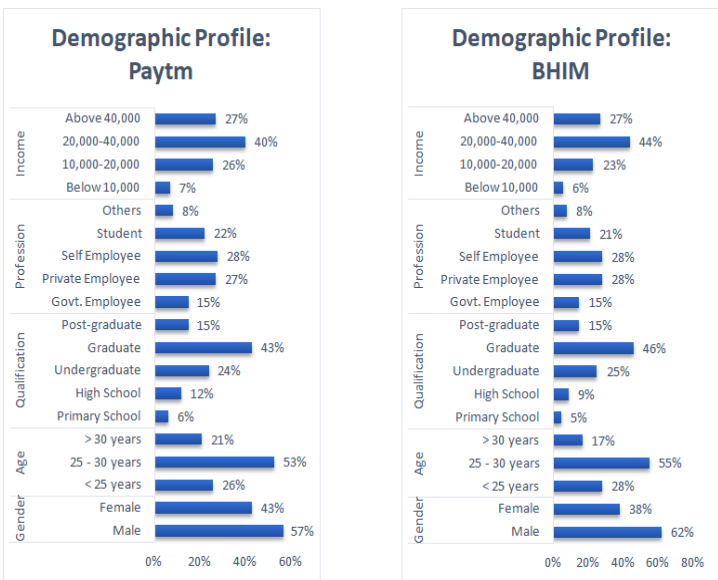

Fig. 5. Demographic Profile of Customers of Paytm and BHIM

\section{B.Analysis of General Background}

The study made an effort to identify the knowledge of customers in relation to the use of cashless payment services. Both Paytm \& BHIM viewed that over $60 \%$ of customers were using the application for at least 1 year. Further, 51\% (for Paytm) \& 55\% (for BHIM) of the respondents' stated that they are comfortable with the use of new technology. Lastly in regards to the factors discouraging in use of cashless payment services, overall, above $80 \%$ (for Paytm) \& above $60 \%$ (for BHIM) of them agreed that non-popularity of the service, the necessity of internet for availing payment service, the necessity of smartphones, wallet transaction fee, lack of confidence using new tech and lack of knowledge discouraged them. From the overall analysis of the perception of respondents on the cashless payment, it's understood that most of the respondents face many problems with the cashless payment service.

\section{Inferential Analysis}

a. Correlation Test:

Table 1: Correlation table for Paytm and BHIM

\begin{tabular}{|c|c|c|c|c|c|c|}
\hline & \multicolumn{3}{|c|}{ Customer Satisfaction for Paytm } & \multicolumn{3}{|c|}{ Customer Satisfaction for BHIM } \\
\hline & $\begin{array}{l}\text { Pearson } \\
\text { Correlation }\end{array}$ & $\begin{array}{l}\text { Sig. (2- } \\
\text { tailed) }\end{array}$ & $\mathrm{N}$ & $\begin{array}{c}\text { Pearson } \\
\text { Correlation }\end{array}$ & $\begin{array}{l}\text { Sig. (2. } \\
\text { tanled) }\end{array}$ & $\mathrm{N}$ \\
\hline Good quality of service & & & 100 & & 0.000 & 100 \\
\hline Provides a wide range of product and services & $0.47^{n \times x}$ & 0.000 & 100 & $0.49 m$ & 0.000 & 100 \\
\hline $\begin{array}{l}\text { at s single platronm } \\
\text { Clear instructions and directions for the service }\end{array}$ & $0.83 * * 8$ & 0.000 & 100 & $0.83^{3 * * *}$ & 0.000 & 100 \\
\hline SMS alent for the transaction & $0.77^{* *+8}$ & 0.000 & 100 & $0.78^{\cdots *}$ & 0.000 & 100 \\
\hline Convenient hours of operation $(24 \times 77$ & $0.91^{* * *}$ & 0.000 & 100 & $0.90^{* 8 *}$ & 0.000 & 100 \\
\hline Problem solving through instant information & $0.89^{n * *}$ & 0.000 & 100 & $0.88^{m+m}$ & 0.000 & \\
\hline Service charges levied by the company & $0.77^{* * *}$ & 0.000 & 100 & $0.69 \% * x$ & 0.000 & 100 \\
\hline Customer feedbark sernices & $0.83 * * 8$ & 0.000 & 100 & $0.833^{2 * * *}$ & 0.000 & 100 \\
\hline $\begin{array}{l}\text { Affordability } \\
\text { Worth }\end{array}$ & 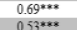 & 0.000 & 100 & $0.76^{20 * *}$ & 0.000 & 100 \\
\hline $\begin{array}{l}\text { Worth price enharged } \\
\text { Differen mobiles }\end{array}$ & $0.57^{* * 8}$ & 0.000 & 100 & $0.8^{28 * x+}$ & 0.000 & $\begin{array}{l}100 \\
100\end{array}$ \\
\hline Internet requirement & $0.69^{* * 8}$ & 0.000 & 100 & $0.898 * x$ & 0.000 & 100 \\
\hline Reduced time of transactions & $0.62^{* * * *}$ & 0.000 & 100 & $0.68^{* * *}$ & 0.000 & 100 \\
\hline $\begin{array}{l}\text { Facilitates payments for all kind of service } \\
\text { Ease of use }\end{array}$ & $0.81^{* * z}$ & 0.0000 & $\begin{array}{l}100 \\
100\end{array}$ & $0.81^{* * * *}$ & 0.0000 & $\begin{array}{l}100 \\
100\end{array}$ \\
\hline Compotibility of application to use with any & $0.69 * 28$ & 0.000 & 100 & $0.848 * x$ & 0.000 & 100 \\
\hline $\begin{array}{l}\text { digital device } \\
\text { Latrst technology being used }\end{array}$ & & 0.000 & 100 & & 0.000 & \\
\hline 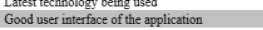 & $0.55^{1 * * 8}$ & 0.000 & 100 & $0.55^{2 * x+}$ & 0.000 & 100 \\
\hline 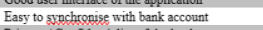 & $0.79^{* * * 8}$ & 0.000 & 100 & $0.78^{8 * *}$ & 0.000 & 100 \\
\hline Privacy / Confidentiality of the bank & $0.83^{* * 8}$ & 0.000 & 100 & $0.82^{2 * * *}$ & 0.000 & 100 \\
\hline Security & $0.74^{* * *}$ & 0.000 & 100 & $0.95^{m *+}$ & 0.000 & 100 \\
\hline
\end{tabular}

The Pearson correlation used in table 1, to understand the relationship between the dependent variable and the independent variables resulted significantly at $p<0.05$ for almost all the variables. Out of all the independent variables, with respect to 'Paytm' 'Convenient hours of operation (24 X7)' (0.91***) and 'Problem-solving through instant information' ( $\left.0.89^{* * *}\right)$; and for BHIM 'Convenient hours of operation (24 X7)' (0.91***) and 'Security' (0.95***) depict the highest correlation with customers' satisfaction level. In this regard, Singh and Rana [18] similarly mentioned that majority of the respondents agree that mobile wallet/digital payment provides satisfaction to consumers in terms of various benefits available such as communication, feedback service, problem solutions and privacy in retaining the data. A similar study by Reddy and Reddy [40] mentioned that online banking services available via e-wallets entails ease in using the services anywhere and everywhere. These benefits regarding Paytm, in turn, improved use of products, quality of decision as compared to traditional methods. On the contrary BHIM reflect customer satisfaction in terms of better security, on-time and quality service offerings over other competitors.

b. Regression Analysis

Table 2: ANOVA table for Paytm and BHIM

\begin{tabular}{llllllll|}
\hline ANOVA & & & & & & \\
\hline Model & & Df & Sum & Mean & F value & Sig \\
& Regression & 20 & 43.03 & 43.03 & 71.06 & 0.00 \\
\hline \multirow{2}{*}{ Paytm } & Residual & 79 & 2.56 & 0.03 & & \\
& Total & 99 & 45.59 & 43.06 & & \\
& Regression & 21 & 39.11 & 39.11 & 134.30 & 0.00 \\
\hline \multirow{2}{*}{ BHIM } & Residual & 78 & 1.20 & 0.02 & & \\
& Total & 99 & 40.31 & 39.13 & & \\
\hline
\end{tabular}

The ANOVA shows in table 2, that the null hypothesis, i.e. there is no impact of cashless payment services on the satisfaction level of the customers, is rejected since the $\mathrm{F}$ value is significant at $p<0.05$. In addition the $F$ - value is high 71.060 (in case of Paytm) \& 134.300 (in case of BHIM) and so the probability for accepting alternative hypothesis results is quite high.

Table 3: Model Summary

\begin{tabular}{lllll}
\hline \multicolumn{3}{l}{ Model Summary } & & \\
\hline Model & $\mathrm{R}$ & $\mathrm{R}$ & $\begin{array}{l}\text { Adjusted } \\
\text { R Square }\end{array}$ & $\begin{array}{l}\text { Std. The error } \\
\text { of the Estimate }\end{array}$ \\
Paytm & 0.929 & 0.947 & 0.934 & 0.18 \\
BHIM & 0.961 & 0.976 & 0.963 & 0.124 \\
\hline
\end{tabular}

Calculated value for R square in Table 3, are $0.947 \& 0.976$, and adjusted R square are $0.934 \& 0.963$ for Paytm \& BHIM respectively in the model summary. Values are higher than the standardized value of 0.5 . So, the result indicates that more than $90 \%$ of the variation is contributed by the independent variables in the dependent variable.

Table 4: Regression Analysis for Paytm and BHIM

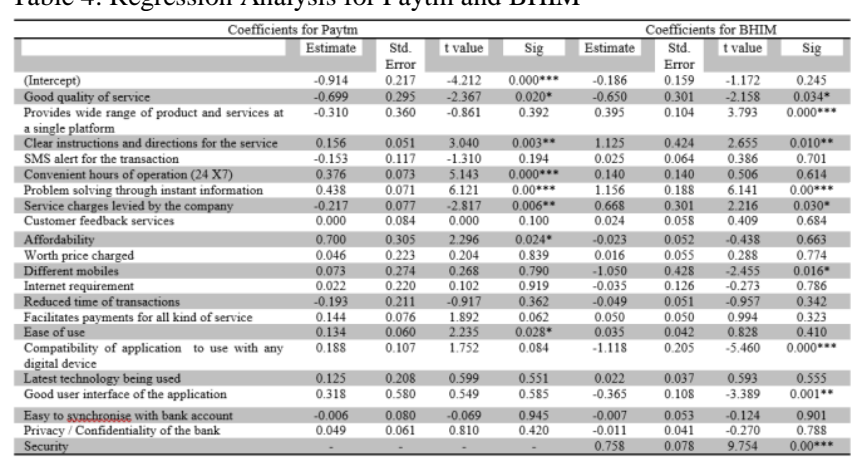

Published By: 
The coefficient regression table 4, shows that among all the significant variables of Paytm, 'Problem solving through instant information' is the most significant variable that contributes to the positive impact on the customers' satisfaction level since it shares the highest coefficient (0.438), significant at $\mathrm{p}<0.05$. In addition, the variable, 'Service charges levied by the company' is another most significant factor that contributes negatively to customer's satisfaction levels since it shares the highest coefficient (-0.217). In this context, a similar study by Gupta and Yadav (2017) discussed that people are now looking forward to better customer services in the banking sector that can resolve their problems timely and speedily in addition to its popularity and brand name. As far as BHIM is concern 'Security' is the most significant variable that contributes to the positive impact on the customers since it shares the highest coefficient (0.758), significant at $\mathrm{p}<0.05$. 'Compatibility of application to use with any digital device' is another most significant factor that contributes negatively in consumer satisfaction level since it shares the highest coefficient $(-1.118)$, significant at $p<0.05$. This means that though it is insecure to use e-wallets, there is a lack of applicability of the same with digital services.

The study of Alao and Sorinola [41] similarly identified the impact of cashless policy in Nigerian banks with respect to customer satisfaction. A similar correlation and regression analysis where done that resulted in depicting infrastructure improvement to be a major requirement in order to bring out more efficiency in terms of secured content in using the same.

c. Comparative Analysis

Table 5: Comparative Analysis for Paytm and BHIM

\begin{tabular}{lll}
\hline Basis & Paytm & BHIM \\
\hline $\begin{array}{l}\text { Positively related to } \\
\text { customer satisfaction }\end{array}$ & $\begin{array}{l}\text { Problem-solving } \\
\text { through instant } \\
\text { information }\end{array}$ & Security \\
$\begin{array}{l}\text { Negatively related to } \\
\text { customer satisfaction }\end{array}$ & $\begin{array}{l}\text { Service charges } \\
\text { levied by the } \\
\text { company }\end{array}$ & $\begin{array}{l}\text { Compatibility of } \\
\text { application to } \\
\text { use with any } \\
\text { digital device }\end{array}$ \\
\hline
\end{tabular}

Table 5 depicts that there is a significant impact of cashless payment services on customer satisfaction. However, in terms of comparison between the use of Paytm and BHIM, there are quite different results attained. BHIM is found to be much more secured platform among respondents to make transactions. This can be attributed to the fact that it is a government-owned platform and thus there is much faith. However, Paytm is negatively related to customer satisfaction with respect to service charges levied by the company. To this, the company is a privately owned company charges differently for various services provided. Another aspect in consideration directs on the compatibility of application to use with any digital services available. This resulted in being negatively related to customer satisfaction when using BHIM. This indicates that BHIM is not available everywhere to the customer for every service. Overall it can be identified that both the platforms do impact customer satisfaction levels but differently.

\section{CONCLUSION AND DISCUSSION}

In a developing country like India, the spread of internet and Wi-Fi servers is much accompanied with various cybercrimes influencing people's wealth, reputation, social and personal identity. This has much augmented the use of cashless payment mode of transaction in an adequate manner. However, in this regard, there has been a widespread competition put forward by both privately owned companies and government aided platforms that capture major audiences in using the services with an utmost level of satisfaction.

This study chiefly depicted that there are differences in private and government platforms on providing services on cashless payment mechanism in addition to the differences in perceptions of customers in terms of using the same. The present study has though identified that there is much impact on customer satisfaction with respect to services of Paytm and BHIM but there are differences in terms of their applicability, availability as well as functionality. Moreover, this analysis indicates that there is need to focus on involving other factors such as intention to use, innovation, discounts-offers etc. that attracts individual in using a service be it from the government or privately owned platform. This study further implicates that there is a need to derive insights on other strategies like security, multi-functionality and other automated features that can be implemented by both private as well as government platforms in gaining customer satisfaction as well as loyalty. This will aid in identifying a comparative analysis on how strategies are different in these platforms and how they can be improved on that ground. In the future, since the e-wallet system is expected to rise even further in presence across rural India, it is recommended to the companies that they keep in mind the above factors while devising their marketing and promotional strategy, as well as while devising the product design. However, after conducting this study, the researcher recognized that a qualitative analysis via interviews with managers of the selected companies would aid in previewing the base for a much detailed comparative study and thus leaving it for the future scope.

\section{REFERENCES}

1. Sagayarani, D. (2017), "Digital payments in India", IOSR Journal of Business and Management, pp. 28-33.

2. Sahu, G.P. and Singh, N.K. (2017), "Paradigm Shift of Indian Cash-Based Economy to Cash-Less Economy: A Study on Allahabad City", in proceeding of the International Conference on e-Business, e-Services and e-Society, Springer, New Delhi, India, pp. 453-461.

3. Bansal, S. and Bansal, I. (2018), "Consumer engagement in electronic word-of-mouth on social networking sites", ELK Asia Pacific Journal of Marketing and Retail Management, Vol. 7 No. 2, pp. 1-27.

4. Rajanna, K.A. (2018), "Growth of Cash-Less Transactions in India: Challenges And Prospects", International Journal of Engineering Development and Research, Vol. 6 No. 1, pp. 199-204

5. Naik, B.K. (2017), "Cashless India : A boon or a bane", International Journal of Applied Research, Vol. 3 No. 6, pp. 525-530.

6. Layak, S. (2017), "After note ban boost, it's time for the next growth trigger for Paytm",available at: https://economictimes.indiatimes.com/small-biz/startups/after-note-b an-boost-its-time-for-the-next-growth-trigger-for-paytm/articleshow/6 1510703.cms (accessed 26 October 2018).

7. Podile, V. and Rajesh, P. (2017), "Public Perception on Cashless Transactions in India", Asian Journal of Research in Banking and Finance, Vol. 7 No. 7, pp. 63-77. 
8. Nazimsha, S. and Rajeswari, M. (2018), "A study on Paytm services in promoting cashless economy after demonetization in India and an outline on its support towards making India digital", International Journal of Pure and Applied Mathematics, Vol. 119 No. 7, pp. 263-278.

9. Venkatesan, T. (2018), "Usage of Paytm - A Study in Madurai City", Bodhi International Journal of Research in Humanities, Arts and Science, Vol. 2 No. 3, pp. 141-144.

10. Vikas, D. and Kumar, A.A. (2018), "What Indians Think About Paytm", World Science News, Vol. 110, pp. 184-196.

11. Bhuvaneswari, M.D. (2017), "An Intellectual Study on Preference towards the Usage of Electronic Wallets among Urban Population of Chennai City", Imperial Journal of Interdisciplinary Research, Vol. 3 No. 9, pp. 2454-1362.

12. Sarika P. and Vasantha S. (2018), "Review on Influence of Trust on Mobile Wallet Adoption and its Effect on Users' Satisfaction", International Journal of Management, Technology and Engineering, Vol. 8 No. 12, pp. 1731-1744.

13. Roy, N. C., and Viswanathan, T. (2018). Impact of Technological Disruption on Workforce Challenges of Indian Banks-Identification,

14. Singh, B. P., Grover, P., \& Kar, A. K. (2017, November). Quality in mobile payment service in India. In Conference on e-Business, e-Services and e-Society (pp. 183-193). Springer, Cham.

15. Mahor N. (2017), "A Study of the Customer Perception of the Risk", Kaav International Journal of Economics, Commerce \& Busines Management, Vol. 4 No. 4, pp. 103-119.

16. Vashista, M. (2017), "Awareness of consumers regarding various modes of cashless transactions", International Journal of Academic Research and Development, Vol. 2 No. 4, pp. 726-729.

17. Shankar, A. and Kumari, P. (2016), "Factors affecting mobile banking Commerce, Vol. 21 No. 1, pp. 479-483.

18. Singh, S. and Rana, R. (2017), "Study of Consumer Perception of Digital Payment Mode", Journal of internet banking and commerce, Vol. 22 No. 3, pp. 1-14.

19. Sahu, G.P. and Naveen Kumar Singh (2018), "Identifying Critical Success Factor (CSFs) for the Adoption of Digital Payment Systems: A Study of Indian National Banks", in Dwivedi, Y.K., Rana, N.P., Slade, E.L., Shareef, M.A., Clement, M., Simintiras, A.C. and Lal, B. (Eds.) Emerging Markets from a Multidisciplinary Perspective: Challenges, opportunities and Research Agenda, Springer, pp. 61-73.

20. Vindhya, K.T. (2015), "A conceptual research on the impact of immediate mobile payment system/interbank mobile payment system (IMPS) on the upliftment of banking transactions in India", International Journal of Applied Research, Vol. 1 No. 13, pp. 709-711.

21. D'souza, R. (2018), "Cashless India: Getting Incentives Right", ORF Occational Paper, pp. 1-50.

22. Ramya, N., Sivasakthi, D. and Nandhini, M. (2017), "Cashless transaction: Modes, advantages, and disadvantages", International Journal of Applied Research, Vol. 3 No. 1, pp. 122-125.

23. Oliver, R.L. (1997), Satisfaction: A Behavioral Perspective on the Consumer, New York, NY: Irwin-McGraw-Hill.

24. Asiyanbi, H.B. and Ishola, A.A. (2018), "E-banking services impact and customer satisfaction in selected bank branches in Ibadan metropolis, Oyo state, Nigeria", Accounting, Vol. 4 No. 4, pp. $153-160$.

25. Muluka K.O.H. (2015), Influence of Digital Banking on Customer Satisfaction: A Case of National Bank of Kenya Bungoma County (Master's Thesis). University of Nairobi. Retrieved from: http://erepository.uonbi.ac.ke/bitstream/handle/11295/90293/Muluka Influence\%20of\%20digital\%20banking\%20on\%20customer\%20sati sfaction.pdf?sequence $=3$.

26. Gyambrah, K. (2016), "The Contribution of Electronic Banking to Customer Satisfaction: A Case of Gcb Bank Limited - Koforidua", International Journal of Managing Information Technology, Vol. 8 No. 1, pp. 1-11.

27. Sangwan, S. and Pau, L.F. (2005), "Diffusion of Mobile Phones in China", ERIM Report Series Research in Management, pp. 1-13.

28. Kabu Khadka, A. and Maharjan, S. (2017), Customer Satisfaction And Customer Loyalty (Master's Thesis). Centria University of Applied Sciences. Retrieved from: $\% 20 \% 20$ and $\% 20 \% 20$ maharjan_\%20soniya.pdf?sequence $=1$.

29. Gupta, N. and Yadav, A. (2017), "The Effect of Electronic Payment on Customer Satisfaction", International Journal of Advance Research and Innovation Ideas in Education, Vol. 3 No. 3, pp. 3556-3579. Assessment \& Mitigation. adoption behavior in India", Journal of Internet Banking and https://www.theseus.fi/bitstream/handle/10024/139650/khadka_kabu

30. Geroski, P.A. (1999), "Models of Technology Diffusion", Research Policy, Vol. 29 No. 4-5, pp. 603-625.

31. Sharma, G., Shakya, S. and Kharel, P. (2014), "Technology Acceptance Perspectives on User Satisfaction and Trust of E-Government Adoption", Journal of Applied Sciences, Vol. 14 No. 9 pp. $860-872$.

32. Surendran, P. (2012), "Technology Acceptance Model : A Survey of Literature", International Journal of Business and Social Research, Vol. 2 No. 4, pp. 175-178.

33. Olumide, O.D. (2016), "Technology Acceptance Model as a predictor of using information system' to acquire information literacy skills", Library Philosophy and Practice (e-journal), pp. 1-27.

34. Mugo, D. Njagi, K. Chemwei, B. and Motanya, J. (2017), "The Technology Acceptance Model (TAM) and its Application to the Utilization of Mobile Learning Technologies", British Journal of Mathematics \& Computer Science, Vol. 20 No. 4, pp. 1-8.

35. Kalpesh J.M. (2018), "Digital Payment: Surprising trends emerge from rural India", available at: https://www.financialexpress.com/opinion/digital-payment-surprising -trends-emerge-from-rural-india/1303964/ (accessed 6 November 2018).

36. Singhraul, B.P. and Garwal Y.S. (2018), "Cashless Economy Challenges and Opportunities in India", Pacific Business Review International, Vol. 10 No. 9, pp. 54-63.

37. Kulkarni, S. and Taj, A.S. (2019), "Digital Payments : Challenges and Solutions",IOSR Journal of Business and Management, pp. 50-55.

38. Nochai R. and Nochai T. (2013), "The Impact of Internet Banking Service on Customer Satisfaction in Thailand: A Case Study in Bangkok", International Journal of Humanities and Management Sciences, Vol. 10 No. 1, pp. 2320-2344.

39. Singh, N.K., Sahu, G.P., Rana, N.P., Patil, P.P., \& Gupta, B. (2018), "Critical Success Factors of the Digital Payment Infrastructure for Developing Economies", in Elbanna, A., Dwivedi, Y.K., Bunker, D., Wastell, D. (Eds.) International Working Conference on Transfer and Diffusion of IT, Springer, pp. 113-125

40. Maken, P. and Shekhar, S. (2017), "Demonetization : A Game Changer from Black Economy to Digital Economy", CLEAR International Journal of Research in Commerce and Management, Vol. 8 No. 11, pp. 5-9.

41. Reddy, D.K. and Reddy, D.M.S. (2015), "A Study on Customer's Perception and Satisfaction towards Electronic Banking in Khammam District", IOSR Journal of Business and Management, Vol. 17 No. 12, pp. 20-27.

42. Alao, A.A. and Sorinola, O.O. (2015), "Cashless Policy and Customers' Satisfaction: A Study of Commercial Banks in Ogun State, Nigeria", Research Journal of Finance and Accounting, Vol. 6 No. 2, pp. $37-47$.

43. Duy P.N.N. and Hoang T.M. (2017), "Factors Affecting Customer Satisfaction and Customer Loyalty the Case of Binh Duong Ceramic Product", in proceeedings of NIDA International Business Conference 2017-Innovation Management: Bridging Theory and Practice, Bangkok, Thailand, p. 380.

44. Islam, M.S., and Gronlud, A. (2011), "Factors Influencing the Adoption of Mobile Phones among the Farmers in Bangladesh Theories and Practices", International Journal on Advances in ICT for Emerging Regions (ICTer), Vol. 4 No. 1, pp. 4-14.

45. Olson, D.L., and Kesharwani, S. (2010), "Enterprise information system trends", in proceeding of the International Conference on Enterprise Information Systems, Springer, Funchal, Madeira-Portugal, pp. 3-14.

\section{AUTHOR'S PROFILE}

Neelu Tiwari is currently working in Jaipuria Institute of Management, Ghaziabad, India

Naveen Kumar Singh is presently working in School of Management Studies, Motilal Nehru National Institute of Technology Allahabad, Prayagraj, India, rajput.naveen07@gmail.com 